\title{
A framework for the technical evaluation of residential buildings' energy retrofit
}

\author{
Annamaria Belleri ${ }^{1, *}$, Chiara Dipasquale ${ }^{1}$, and Jennifer Adami ${ }^{1}$ \\ ${ }^{1}$ Eurac Research, Institute for Renewable Energy, 39100 Bolzano, Italy
}

\begin{abstract}
Despite a wide range of energy-efficient technologies, financial products and public incentives are already available, the private as well as the public sector are struggling to invest in energy efficient solutions for buildings. The primary barriers are the high initial cost and the uncertain payback period of the energy refurbishment. Allowing for different scenario testing and considering interactions among different building energy systems, building energy simulation tools can help investors overcoming such barriers by offering support to the technical planning of energy refurbishment kits through quantitative information rather than qualitative. The energy performance and comfort of three reference multifamily residential buildings typologies were evaluated considering three envelope retrofitting performance levels (high-medium-low insulated and airtight) and different heating and domestic hot water systems (heat pump, boiler, district heating). The tested envelope retrofitting performance levels allow for heating need reduction between $50 \%$ and $90 \%$ compared to the reference case. The active cooling system is not accounted for and building energy simulations outputs include thermal comfort evaluation and overheating risk assessment during the summer season. The potential of photovoltaic system combined with heat pump is evaluated in the three reference cases leading to up to $30 \%$ of load coverage.
\end{abstract}

\section{Introduction}

Despite a wide range of energy-efficient technologies, financial products and public incentives are already available, the private as well as the public sector are struggling to invest in energy efficient solutions for buildings. The primary barriers are the high initial cost and the uncertain payback period of the energy refurbishment. Moreover, investors do not know which energy saving solution is the optimal according to their requirements. Investors are confused by the complexity and the fragmentation of the energy refurbishment market and sometimes they distrust the multiple actors and the different interests involved along the energy refurbishment process. Allowing for different scenario testing and considering interactions among different building energy systems, building energy simulation tools can help investors overcoming such barriers by offering support to the technical planning of energy refurbishment kits through quantitative information rather than qualitative. The paper provides a methodological framework to perform feasibility studies of energy retrofits.

The work presented is part of the EFRE-FESR KlimaKit project which has the objective to drive and foster the Architecture Engineering Construction (AEC) and energy sector to collaborate in the development of integrated solutions for energy retrofit of residential buildings.

\section{Retrofit packages}

There are some preconditions that could become drivers for building energy retrofit intervention. For example, extraordinary maintenance interventions can be easily combined with energy retrofit intervention reducing expenses and improving indoor environment quality.

We developed four retrofit packages leading to different level of intervention. Table 1 reports main drivers identified for the social housing building stock in South Tyrol and the retrofit packages developed to cope with these drivers.

Table 1. Retrofit packages.

\begin{tabular}{|l|l|l|l|}
\hline \multicolumn{2}{|l|}{ Retrofit package } & Drivers & $\begin{array}{l}\text { Intervention } \\
\text { type }\end{array}$ \\
\hline $\begin{array}{l}\text { KlimaKit } \\
\text { BASE }\end{array}$ & $\begin{array}{l}\text { Deterioration } \\
\text { of envelope } \\
\text { physical } \\
\text { properties }\end{array}$ & $\begin{array}{l}\text { Envelope } \\
\text { retrofit }\end{array}$ \\
\hline $\begin{array}{l}\text { KlimaKit } \\
\text { FULL }\end{array}$ & & $\begin{array}{l}\text { Deterioration } \\
\text { of envelope } \\
\text { physical } \\
\text { properties; } \\
\text { Obsolete } \\
\text { indoor space } \\
\text { distribution; }\end{array}$ & $\begin{array}{l}\text { Envelope } \\
\text { retrofit } \\
\text { Heat pump } \\
\text { installation } \\
\text { and new } \\
\text { radiant } \\
\text { system } \\
\text { distribution }\end{array}$ \\
\hline
\end{tabular}

\footnotetext{
* Corresponding author: annamaria.belleri@eurac.edu
} 


\begin{tabular}{|c|c|c|c|}
\hline \multicolumn{2}{|c|}{ Retrofit package } & \multirow{2}{*}{$\begin{array}{l}\text { Drivers } \\
\text { Need of new } \\
\text { functionalities. }\end{array}$} & \multirow{2}{*}{$\begin{array}{l}\text { Intervention } \\
\text { type }\end{array}$} \\
\hline & & & \\
\hline $\begin{array}{l}\text { KlimaKit } \\
\text { FLEXI }\end{array}$ & & $\begin{array}{l}\text { Deterioration } \\
\text { of envelope } \\
\text { physical } \\
\text { properties; } \\
\text { District } \\
\text { heating } \\
\text { network } \\
\text { availability }\end{array}$ & $\begin{array}{l}\text { Envelope } \\
\text { retrofit } \\
\text { District } \\
\text { heating } \\
\text { connection }\end{array}$ \\
\hline $\begin{array}{l}\text { KlimaKit } \\
\text { nZEB }\end{array}$ & & 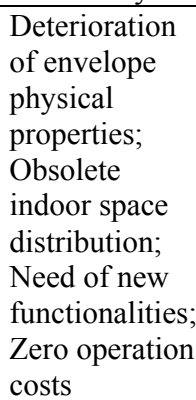 & $\begin{array}{l}\text { Envelope } \\
\text { retrofit } \\
\text { Heat pump } \\
\text { installation } \\
\text { and new } \\
\text { radiant } \\
\text { system } \\
\text { distribution } \\
\text { PV } \\
\text { installation }\end{array}$ \\
\hline
\end{tabular}

\subsection{Envelope performance levels}

For each retrofit package, three levels of envelope retrofitting have been considered:

- Level 1: envelope thermal transmittance and air tightness comply with minimum requirements of national and local regulation for buildings undergoing retrofit intervention;

- Level 2: envelope thermal transmittance and air tightness comply with minimum requirements of national and local regulation to access for incentives;

- Level 3: envelope components and air tightness have performance that allow to reach the target of nearly zero energy (nZEB). In this case mechanical ventilation is installed to keep acceptable indoor air quality (IAQ) levels.

Table 2. Envelope performance levels after retrofit.

\begin{tabular}{|c|c|c|c|c|c|c|}
\hline 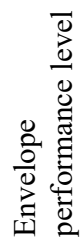 & 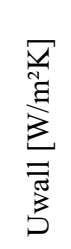 & 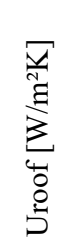 & 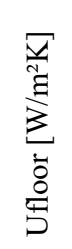 & 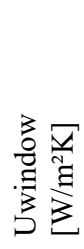 & 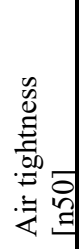 & 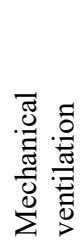 \\
\hline 1 & $\begin{array}{l}\leq \\
0.33\end{array}$ & $\begin{array}{c}\leq \\
0.29\end{array}$ & $\begin{array}{c}\leq \\
0.32\end{array}$ & $\begin{array}{c}\leq \\
2.20\end{array}$ & 3 & - \\
\hline 2 & $\begin{array}{c}\leq \\
0.22\end{array}$ & $\begin{array}{c}\leq \\
0.19\end{array}$ & $\begin{array}{c}\leq \\
0.23\end{array}$ & $\begin{array}{c}\leq \\
1.30\end{array}$ & 1.5 & - \\
\hline 3 & $\begin{array}{c}\leq \\
0.15\end{array}$ & $\begin{array}{c}\leq \\
0.15\end{array}$ & $\begin{array}{c}\leq \\
0.20\end{array}$ & $\begin{array}{c}\leq \\
1.00\end{array}$ & 0.6 & $\begin{array}{c}0.6 \\
1 / \mathrm{h} \\
\mathrm{HR} \\
70 \\
\%\end{array}$ \\
\hline
\end{tabular}

Table 2 reports envelope characteristics for the three envelope performance levels above mentioned. In case of envelope level 1 and 2 existing windows are replaced with a double-glazing system, while in case of envelope level 3 existing windows are replaced with a triple glazing system. Insulation thickness ranges from 10 to $20 \mathrm{~cm}$ over the three envelope performance levels. Due to the low infiltration rates for envelope level 3, mechanical ventilation with heat recovery $(70 \%)$ is installed providing $0.61 / \mathrm{h}$ air changes to keep an acceptable IAQ during occupied time.

\subsection{Criteria for selection of heating/DHW system}

The reduction of the building consumptions is achieved not only by reducing the building demands, but also improving the heating and cooling system efficiency. Intervention on the envelope can be accompanied with the replacement of the generation or distribution system.

The choice for identifying the heating and Domestic Hot Water (DHW) system to be installed after retrofit can be driven by technical requirements as listed in Table 3 . The first column lists the technical requirements needed for each of the individuated solutions: district heating (DHC), conditioning boiler (COND), biomass boiler (BIOM), airto-water heat pump (AWHP) and water-to-water heat pump (WWHP) for the generation unit, while fan coils (FANC), radiators (RADT) or radiant panels (RPAN) as distribution systems.

Whenever the connection to a district heating grid is available, this represents the first choice for covering the heating loads (space heating and DHW demand). In case of space cooling demand, a split unit is installed for covering this other load.

The installation of a boiler is suggested especially in case of rigid external temperatures and high peak loads for space heating as its functioning is not influenced by external weather conditions and can work at higher supply temperatures. The choice between a condensing or biomass boiler is influenced by two requirements: for the first type of boiler, the presence of a connection with the gas grid, while for the other the possibility to stock the biomass in a technical room.

Heat pumps represent the optimal choice whenever the peak load for space heating is low, and this is the case for the retrofitted buildings. Moreover, in case of a cooling load, there is not the need to install another system because a heat pump can be used for both uses. In case of low external temperatures $\left(0 \div-5^{\circ} \mathrm{C}\right)$, the heat pump does not perform properly and, eventually, it should be coupled with another generation system that works when external temperatures drop down.

In case the dwellings are occupied during retrofitting works, the installation of radiant panels is not possible unless the occupants should leave the apartments for few days. In these cases, the adoption of radiators or fan coils facilitates the installation reducing the impact on the tenants. Radiators and fan coils represent the optimal solution also in case of high peak loads, while radiant panels find the best application in low demanding buildings, that is, again, the case of retrofitted buildings. Fan coils and radiant panels are suitable for covering cooling loads. 
Table 3. Checklist technical requirements for HVAC generation and distribution selection.

\begin{tabular}{|l|l|l|l|l|l|l|l|l|}
\multicolumn{1}{|c|}{ GENERATION } & \multicolumn{3}{c|}{ DISTRIBUTION } \\
\hline & & & \\
\hline
\end{tabular}

\subsection{Criteria for photovoltaic (PV) plant optimization}

The cost-optimal capacity of photovoltaic system combined with heat pump is evaluated in the three reference cases. The PV configuration (capacity and position of the modules) is defined with the support of an optimization software tool ([1], [2]). The tool takes into account the building geometry, the irradiation context, the energy demand and other techno-economic aspects (i.e. electricity price, cost of $\mathrm{PV}$, cost of storage, PV degradation, maintenance costs, discount rate) (Figure 1). It aims to maximize the system self-consumption and the Net Present Value (NPV).

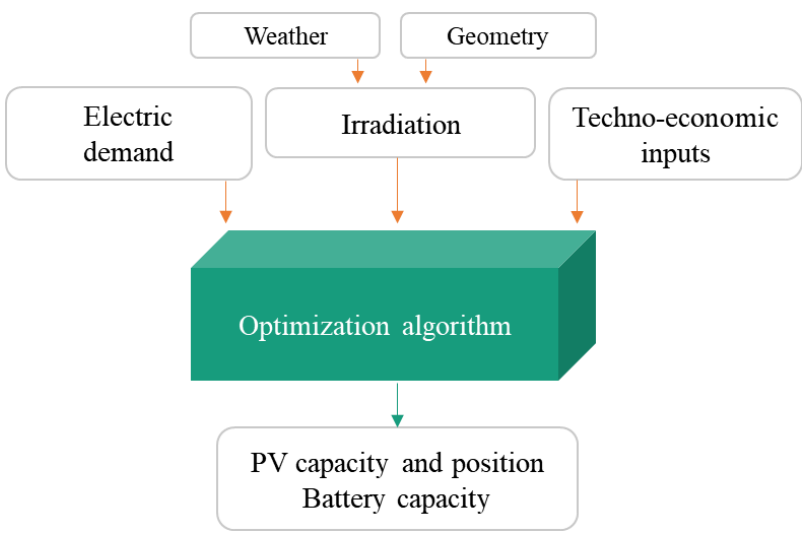

Figure 1. Flow chart representing the PV optimization process.

\section{Reference buildings}

Three reference buildings, owned by the social housing institute of Bolzano, were selected as case studies being representative of the social housing building stock of the Province of Bolzano. The three reference buildings represent three widely diffused residential building typologies. All of them are located in the surroundings of Merano (north-east of Italy), characterized by 2863 heating degrees.

\subsection{Big multifamily house - Construction period 1976-91}

First case study (Figure 2) is a big multifamily house with 6 floor above ground and located in an urban surrounding. Each floor has four apartments served by two staircases. Garage, technical rooms, cellar and the thermal power plant are located in the underground floor. Ground floor is open and is of service for bike parking and access to staircases.

Table 4. First reference building characteristics.

\begin{tabular}{|l|l|}
\hline Construction period & $1976-91$ \\
\hline Number of floors above ground & 6 \\
\hline Number of dwellings & 24 \\
\hline Gross volume $\left[\mathrm{m}^{3}\right]$ & 7490 \\
\hline Net heated surface $\left[\mathrm{m}^{2}\right]$ & 2061 \\
\hline Surface/volume ratio & 0,42 \\
\hline Average U-value of the envelope $\left[\mathrm{W} / \mathrm{m}^{2} \mathrm{~K}\right]$ & 0,99 \\
\hline Heating need $\left[\mathrm{kWh} / \mathrm{m}^{2} \mathrm{a}\right]$ & 107 \\
\hline
\end{tabular}

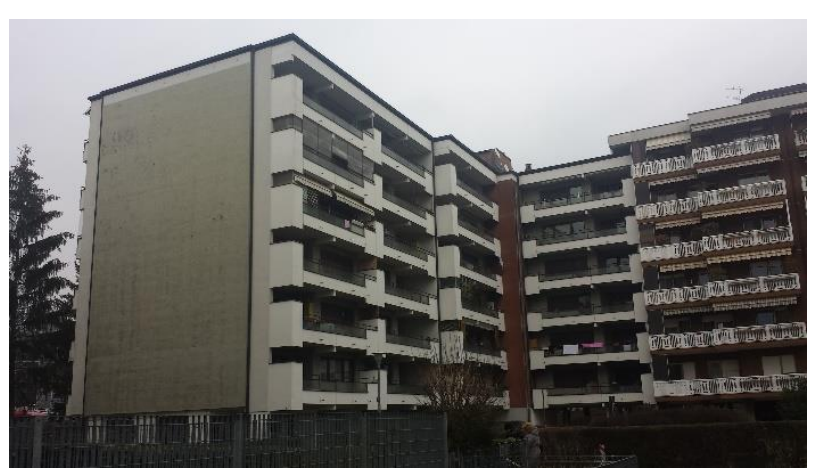

Figure 2. First reference building. 


\subsection{Small multifamily house - Construction period 1976-91}

Second case study (Figure 3) is a small multi-family house typical of social housing in small villages of the South Tyrolean valleys. It has 16 apartments located over three floors, ground floor included. Garage, technical rooms, cellar and the thermal power plant are located in the underground floor.

Table 5. Second reference building characteristics.

\begin{tabular}{|l|l|}
\hline Construction period & $1976-91$ \\
\hline Number of floors above ground & 2 \\
\hline Number of dwellings & 16 \\
\hline Gross volume $\left[\mathrm{m}^{3}\right]$ & 4570 \\
\hline Net heated surface $\left[\mathrm{m}^{2}\right]$ & 1189 \\
\hline Surface/volume ratio & 0,51 \\
\hline Average U-value of the envelope $\left[\mathrm{W} / \mathrm{m}^{2} \mathrm{~K}\right]$ & 1,34 \\
\hline Heating need $\left[\mathrm{kWh} / \mathrm{m}^{2} \mathrm{a}\right]$ & 229 \\
\hline
\end{tabular}

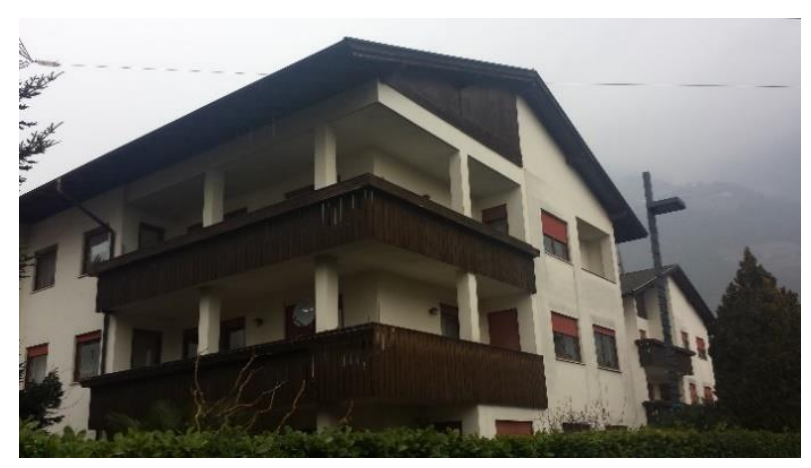

Figure 3. Second reference building.

\subsection{Small multifamily house - Construction period 1946-75}

Third case study (Figure 4) is a small multifamily house built in the post war period. The building is part of a district with other 5 similar buildings. It has 3 floors above ground and a semi-grounded floor. Each floor has two identical apartments connected to one staircase.

Table 6. Third reference building characteristics.

\begin{tabular}{|l|l|}
\hline Construction period & $1946-75$ \\
\hline Number of floors above ground & 3 \\
\hline Number of dwellings & 6 \\
\hline Gross volume $\left[\mathrm{m}^{3}\right]$ & 1588 \\
\hline Net heated surface $\left[\mathrm{m}^{2}\right]$ & 519 \\
\hline Surface/volume ratio & 0,7 \\
\hline Average U-value of the envelope $\left[\mathrm{W} / \mathrm{m}^{2} \mathrm{~K}\right]$ & ca 1,4 \\
\hline Heating need $\left[\mathrm{kWh} / \mathrm{m}^{2} \mathrm{a}\right]$ & $75-150$ \\
\hline
\end{tabular}

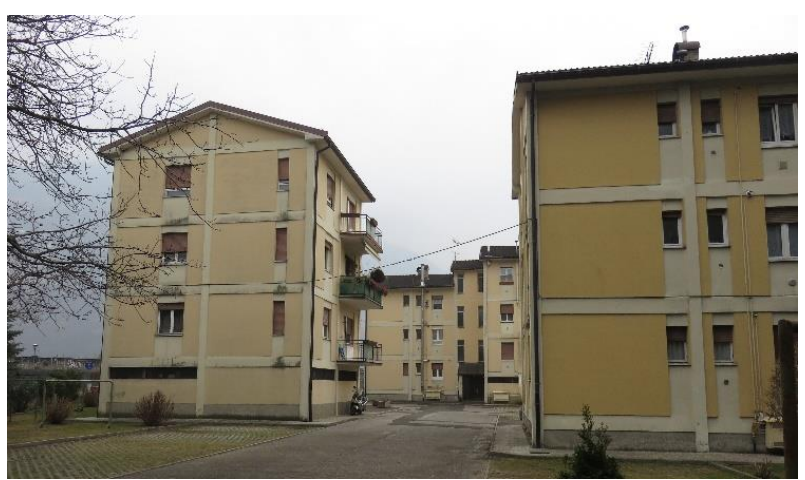

Figure 4. Third reference building.

\section{Methodological approach to energy simulation}

The building behaviour throughout the year depends on the building geometry and physics, but also on occupancy, ventilation rates and weather conditions. These last aspects can be properly taken into account in dynamic simulations where a building with its gains and losses are simulated during one year. The building consumption depends not only on the building demand, but also on the HVAC system performance. Capacity effects, solar contribution and components efficiency can be considered in dynamic simulation models.

Allowing for different scenario testing and considering interactions among different building energy systems, building energy simulation tools can take into account energy dynamics and interaction among building systems. Reference buildings were modelled in Trnsys simulation environment [7]. Each apartment within the reference buildings is represented by a thermal zone.

Simulations are performed with a 15 min timestep over a whole reference year. Weather file is generated by Meteonorm [7] for a typical meteorological year in Merano (Italy) climate. Typical outdoor temperatures over the typical meteorological year are represented by the graph in Figure 5.

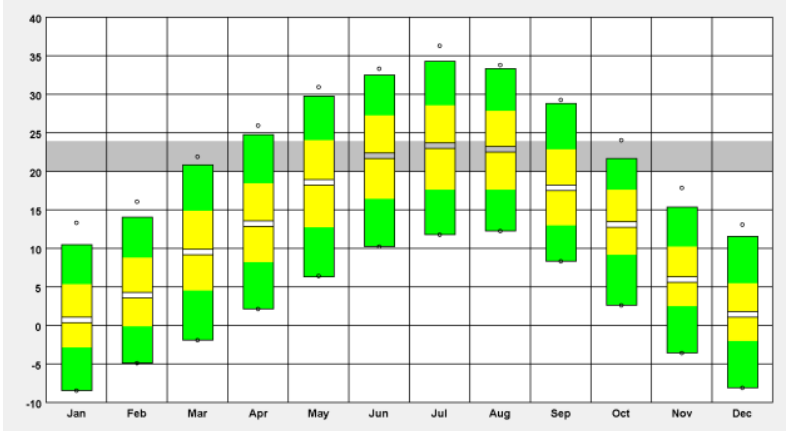

Figure 5. Outdoor temperatures range over a typical meteorological year in Merano climate. Source: Climate Consultant 6.0.

\subsection{Assumptions on building use}

Occupancy profiles of each apartment/thermal zone are generated by a stochastic model [7] that takes into account the contemporaneity use in a multi-family house avoiding 
the simultaneity of all the apartments. Occupancy profiles distinguish between three occupant status:

- Active: tenants are at home and not sleeping;

- Sleeping: tenants are at home and asleep;

- Absent: tenants are not at home.

According to typical metabolic rates reported in Ashrae handbook of fundamentals 2009 [7], total heating gain for active tenants are assumed to be $126 \mathrm{~W} /$ person, while for tenants asleep are assumed to be $72 \mathrm{~W} /$ person.

Interior lights are assumed to be on if incident solar radiation on main façade exceeds $140 \mathrm{~W} / \mathrm{m}^{2}$ and occupants' status is active. Lighting power density is assumed to be $7.5 \mathrm{~W} / \mathrm{m}^{2}$ with an overall luminous efficiency of $75 \%$.

Other internal loads due to electric equipment depend on occupants' status:

- if occupants are "sleeping" or "absent" internal loads are considered equal to $2 \mathrm{~W} / \mathrm{m}^{2}$ (20\% of total installed power);

- if occupants are "active" internal loads are considered equal to $6 \mathrm{~W} / \mathrm{m}^{2}(60 \%$ of total installed power, considering a coincidence factor of 0.6 as recommended by the standard UNI TS 11300-1).

Solar shadings ( 0.7 solar factor) are activated if:

- $\quad$ zone temperature is above $24^{\circ} \mathrm{C}$ and

- $\quad$ incident solar radiation on main façade is above 140 $\mathrm{W} / \mathrm{m}^{2}$.

When foreseen (envelope level 3), mechanical ventilation provides $0.61 / \mathrm{h}$ during winter time if occupants are active and $0.3 \mathrm{l} / \mathrm{h}$ when occupants are sleeping.

No cooling system is considered. Natural ventilation contributes to the control of overheating. Windows are assumed to be opened when indoor zone temperature is above $23^{\circ} \mathrm{C}$ and outdoor temperature is lower than zone temperature and greater than $16^{\circ} \mathrm{C}$.

\subsection{Heating and DHW settings}

For the three reference buildings, the same heating and DHW system configuration has been adopted, but different generation and distribution devices are studied, namely:

- $\quad$ existing gas boiler and radiators (KlimaKit BASE)

- district heating and existing radiators (KlimaKit FLEXI);

- heat pump and radiant floor (KlimaKit FULL and nZEB).

The heating and DHW system is modelled and simulated in the TRNSYS environment accounting for the system dynamic behaviour, thermal storages and control strategies. The model is organized in modules in order to be replaced without changing the control rules and connections with the rest of the plant, maintaining therefore the same working conditions.

The layout of the energy plant is reported in Figure 6. The different configurations consist of a centralized generation unit used for providing both space heating and
DHW preparation. Due to the climatic conditions and the building owner typology, in this study, the cooling load is not considered. The studied generation systems are gas boiler, air-to-water heat pump and district heating. For the three cases, energy consumption is calculated and reported in the database.

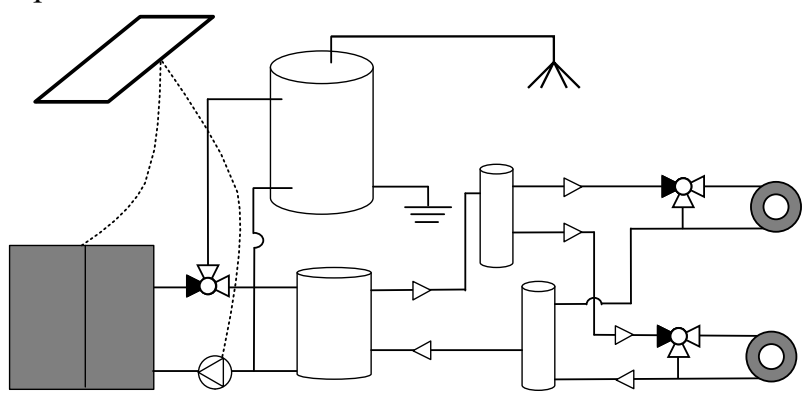

Figure 6. Layout of the adopted HVAC system

The generation unit is sized on the higher thermal load between DHW preparation and space heating. Thanks to the presence of storage tanks, it is possible to manage simultaneous loads with a smaller generation unit capacity. KlimaKit BASE and FLEXI do not include intervention on distribution system, therefore in these cases system distribution relies on existing radiators. A calculation verifies that, the installed radiators' capacity, which was sized to work at higher temperatures in higher peak loads buildings, is enough to cover lower loads and to work at lower supply temperatures as required after building retrofit.

Table 7 summarizes the set temperatures adopted in the system control. The room set point is set at $20^{\circ} \mathrm{C}$ with a hysteresis of $\pm 0.5^{\circ} \mathrm{C}$. This hysteresis, together with the thermal losses due to the distribution and emission, causes a difference between the ideal building demand and the useful energy of the building for maintaining the temperature set point.

Table 7. Set-point values used in the HVAC system

\begin{tabular}{|l|l|l|}
\hline Set parameter & Unit & Value \\
\hline Space heating set temperature & ${ }^{\circ} \mathrm{C}$ & $20 \pm 0.5$ \\
\hline Supply DHW temperature & ${ }^{\circ} \mathrm{C}$ & 45 \\
\hline Supply temperature to radiators & ${ }^{\circ} \mathrm{C}$ & 45 \\
\hline Supply temperature to radiant panels & ${ }^{\circ} \mathrm{C}$ & 35 \\
\hline
\end{tabular}

The system control strategies prioritize the DHW tank charging when there is a simultaneous request with space heating.

\subsection{Assumptions for PV optimization}

For the three reference buildings with nZEB retrofit package performance, the incident radiation (ray-tracing method [7]) and the energy demand of the centralized generation unit are evaluated on hourly timestep. This approach allows to identify the cost-optimal PV configuration to match the $\mathrm{PV}$ production with the building consumption. This ensures that the best possible share of energy produced is directly consumed throughout the year. The Net Present Value (NPV), which is the assumed target function (i.e. the indicator to be 
maximized), is highly affected by the share of energy selfconsumed. In the NPV calculation some techno-economic input is considered, see Table 8 below.

Table 8. Techno-economic input assumed in the PV optimization.

\begin{tabular}{|l|c|}
\hline Input & Value \\
\hline PV module area [m²] & 1.44 \\
\hline PV modules efficiency & 0.2 \\
\hline $\mathrm{N}^{\circ}$ of years for NPV & 25 \\
\hline Price of consumed electricity [€/kWh] & 0.2 \\
\hline Price of sold electricity [€/kWh] & 0 \\
\hline PV system cost [€/kWp] & 1800 \\
\hline Storage cost [€/kWh] & 900 \\
\hline PV modules annual degradation [\%]* & $0.5-1$ \\
\hline Load annual growth [\%]* & $0-2$ \\
\hline Price of electricity annual growth [\%]* & $-1-1$ \\
\hline Price of sold electricity annual growth [\%] & 0 \\
\hline Discount rate [\%]* & $0-4$ \\
\hline Annual cost of maintenance [€/kWp]* & $18-36$ \\
\hline
\end{tabular}

* stochastic input with uncertainty scenarios

\section{Results}

The combination of the envelope energy levels, generation and distribution systems and PV configurations produces a collection of simulation-based results that are gathered in a database. The following paragraphs present some of the obtained results on the adoption of different retrofit packages on the reference buildings.

Since different energy carriers are used in the four retrofit packages, in order to compare their performance, we need to convert the physical units of different energy carriers into uniform metrics. We identified these uniform metrics as operative costs and equivalent $\mathrm{CO}_{2}$ emissions. Table 9 reports the conversion factors applied which represent current cost tariffs and $\mathrm{CO}_{2}$ equivalent emissions conversion factors from the local legislation.

PV generated electricity contributes to the reduction of operative costs only if it is self-consumed. The PV electricity which is not self-consumed is not taken into consideration in the operative cost calculation.

Table 9. Conversion factors for operative costs and $\mathrm{CO} 2$ equivalent emissions.

\begin{tabular}{|r|c|c|}
\hline & Cost $[€ / \mathrm{kWh}]$ & $\begin{array}{c}\mathrm{CO} 2 \text { equivalent } \\
\text { emissions } \\
{[\mathrm{kg} / \mathrm{kWh} \text { final }]}\end{array}$ \\
\hline gas & 0.08 & 0.249 \\
\hline electricity & 0.2 & 0.647 \\
\hline district heat & 0.07 & 0.15 \\
\hline
\end{tabular}

\subsection{Energy performance vs operative costs}

Actual $\mathrm{CO}_{2}$ equivalent emissions for heating and $\mathrm{DHW}$ of reference building 1 is estimated to be $108 \mathrm{kgCO} 2 \mathrm{eq} / \mathrm{m}^{2}-\mathrm{y}$ and operative costs are $13 € / \mathrm{m}^{2}$-y over a typical meteorological year.
Figure 7 reports on the main results obtained for the first reference building with the four retrofit packages (KlimaKit BASE, FLEXI, FULL and nZEB). In particular, costs and $\mathrm{CO}_{2}$ equivalent emission during building operation are compared. KlimaKit BASE package is estimated to reduce $\mathrm{CO}_{2}$ equivalent emissions between $50 \%$ (envelope level 1) and 78\% (envelope level 3 ). The other retrofit packages can reduce $\mathrm{CO}_{2}$ equivalent emissions by up to $95 \%$ and operative costs down to less than $2 € / \mathrm{m}^{2}$.

Compared to electricity energy carrier, district heating has lower cost and lower $\mathrm{CO}_{2}$ equivalent emissions per $\mathrm{kWh}$ of final energy. Therefore, even if KlimaKit FULL retrofit package performance in terms of energy demand are lower than KlimaKit FLEXI retrofit package energy demand, they result in similar performance in terms of $\mathrm{CO}_{2}$ equivalent emissions as well as operation costs.

Despite the higher cost of electricity (in Italy) with respect to gas or district heating, heat pump systems (KlimaKit FULL) allow to achieve lower operation costs compared to other generation systems thanks to the higher heat pump efficiency. KlimaKit nZEB retrofit package allows to achieve the best results in terms of both $\mathrm{CO}_{2}$ equivalent emission and operative costs reduction thanks to the selfproduction.

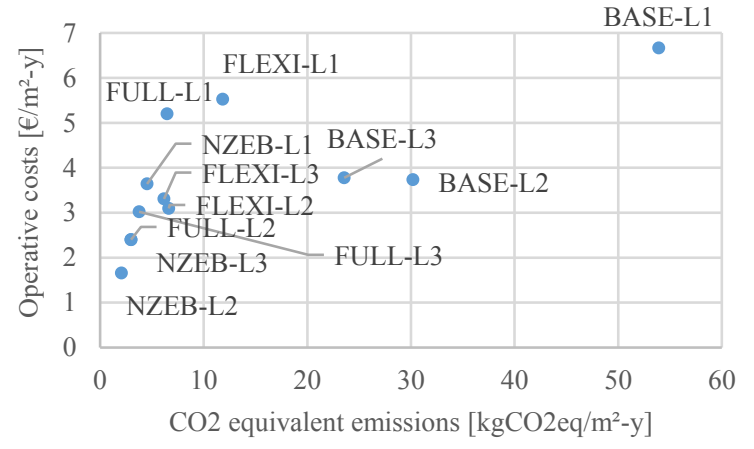

Figure 7. Energy performance and operative costs of first reference building after retrofit packages application with different envelope performance levels (L1-L2-L3).

Similar results are obtained for reference building 2 (Figure 8) and 3 (Figure 9).

Actual $\mathrm{CO}_{2}$ equivalent emissions for heating and $\mathrm{DHW}$ of reference building 2 is estimated to be $144 \mathrm{kgCO} 2{ }_{\mathrm{eq}} / \mathrm{m}^{2} \mathrm{y}$ and operative costs are $18 € / \mathrm{m}^{2}$ over a typical meteorological year. KlimaKit BASE package is estimated to reduce $\mathrm{CO}_{2}$ equivalent emissions between $61 \%$ (envelope level 1) and 78\% (envelope level 3). The other retrofit packages can reduce $\mathrm{CO}_{2}$ equivalent emissions by up to $97 \%$ and operative costs down to $3 € / \mathrm{m}^{2}$-y (Figure 8).

Actual $\mathrm{CO}_{2}$ equivalent emissions for heating and $\mathrm{DHW}$ of reference building 3 is estimated to be $119 \mathrm{kgCO} 2{ }_{\mathrm{eq}} / \mathrm{m}^{2} \mathrm{y}$ and operative costs are $15 € / \mathrm{m}^{2}$ over a typical meteorological year. KlimaKit BASE package is estimated to reduce $\mathrm{CO}_{2}$ equivalent emissions between $60 \%$ (envelope level 1) and 79\% (envelope level 3). The other retrofit packages can reduce $\mathrm{CO}_{2}$ equivalent emissions by up to $97 \%$ and operative costs down to $3 € / \mathrm{m}^{2}$-y (Figure 9). 


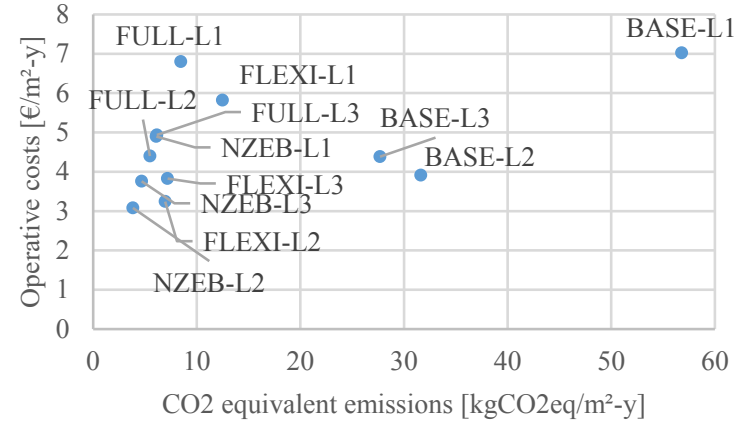

Figure 8. Energy performance and operative costs of second reference building after retrofit packages application with different envelope performance levels (L1-L2-L3).

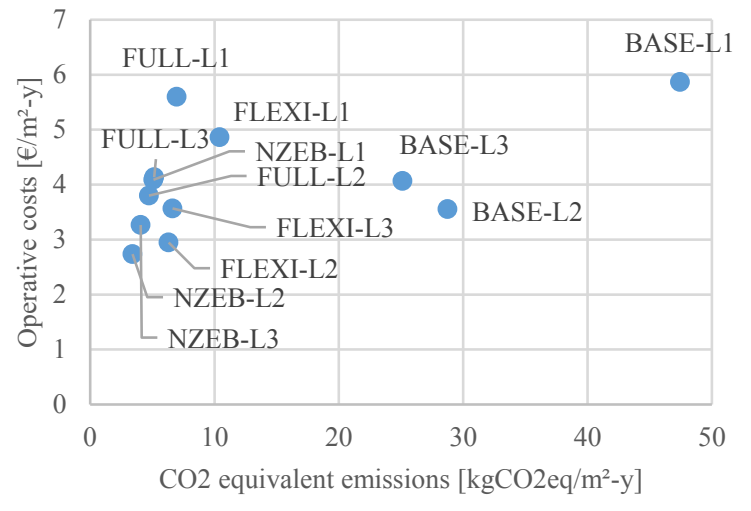

Figure 9. Energy performance and operative costs of third reference building after retrofit packages application with different envelope performance levels (L1-L2-L3).

\subsection{PV production}

In order to assess the KlimaKit nZEB retrofit package performances, the capability of an optimized PV system of covering the electricity demand of a centralized heat pump is assessed for each of the reference buildings and the three energy performance levels considered. In Table 10 the final results are shown, including the optimized PV capacity and its performance in terms of electricity coverage. The PV modules (in red on $3 \mathrm{~d}$ models) are placed both on roof and facades and decrease as consequence of a lower energy demand of the building (envelope performance level) and consequently of the electric demand of the heat pump.

All the performed optimizations result in a circa $30 \%$ of electrical loads coverage, namely the self-consumed electricity over heat pump electricity demand for heating and DHW.

PV system capacity ranges between 2.6 and $4 \mathrm{kWp}$ for reference building 1 , between 18 and $35 \mathrm{kWp}$ for reference building 2 and 6.6 to $13 \mathrm{kWp}$ for reference building 3 .
Table 10. Results of PV system optimization in the three reference buildings.

\begin{tabular}{|c|c|c|c|}
\hline \multicolumn{4}{|c|}{ First reference building } \\
\hline $\begin{array}{l}\text { Energy } \\
\text { performanc } \\
\text { e level }\end{array}$ & 1 & 2 & 3 \\
\hline $\begin{array}{l}\text { Selected } \\
\text { PV }\end{array}$ & & & \\
\hline $\begin{array}{l}\text { PV } \\
\text { capacity } \\
(\mathrm{kWp})\end{array}$ & 4 & 3.4 & 2.6 \\
\hline $\begin{array}{l}\text { El. loads } \\
\text { coverage } \\
(\%)\end{array}$ & 30 & 31 & 31 \\
\hline \multicolumn{4}{|c|}{ Second reference building } \\
\hline $\begin{array}{l}\text { Energy } \\
\text { performanc } \\
\text { e level }\end{array}$ & 1 & 2 & 3 \\
\hline \multicolumn{4}{|l|}{$\begin{array}{l}\text { Selected } \\
\text { PV }\end{array}$} \\
\hline $\begin{array}{l}\mathrm{PV} \\
\text { capacity } \\
(\mathrm{kWp})\end{array}$ & 35 & 21.3 & 18 \\
\hline $\begin{array}{l}\text { El. loads } \\
\text { coverage } \\
(\%)\end{array}$ & 27 & 28 & 29 \\
\hline \multicolumn{4}{|c|}{ Third reference building } \\
\hline $\begin{array}{l}\text { Energy } \\
\text { performanc } \\
\text { e level }\end{array}$ & 1 & 2 & 3 \\
\hline \multicolumn{4}{|l|}{$\begin{array}{l}\text { Selected } \\
\text { PV }\end{array}$} \\
\hline $\begin{array}{l}\text { PV } \\
\text { capacity } \\
(\mathrm{kWp})\end{array}$ & 13.3 & 7.8 & 6.6 \\
\hline $\begin{array}{l}\text { El. loads } \\
\text { coverage } \\
(\%)\end{array}$ & 28 & 30 & 31 \\
\hline
\end{tabular}

\section{Conclusion}

Despite their difference in terms of architecture and actual energy performance, similar results are obtained for the three reference buildings in the retrofit scenario analysed that include four retrofit packages:

- KlimaKit BASE: envelope retrofit only;

- KlimaKit FLEXI: envelope retrofit and connection to the district heating;

- KlimaKit FULL: envelope retrofit, heat pump installation and new radiant system distribution;

- KlimaKit nZEB: envelope retrofit, heat pump installation and new radiant system distribution, PV installation. 
KlimaKit BASE package is estimated to reduce $\mathrm{CO}_{2}$ equivalent emissions between $50 \%$ (envelope level 1) and $80 \%$ (envelope level 3). The other retrofit packages can reduce $\mathrm{CO}_{2}$ equivalent emissions by up to $97 \%$ and operative costs down to $2 € / \mathrm{m}^{2}-\mathrm{y}$. Best performance in terms of costs and $\mathrm{CO}_{2}$ emissions during building operation are achieved thanks to the use of heat pump combined with photovoltaic system, despite the higher cost of electricity (in Italy) with respect to gas or district heating. Thanks to optimization of PV capacity to minimize Net Present Value of the PV plant, PV generated electricity can cover circa $30 \%$ of electrical loads of the heat pump over the whole year.

A database collects reference building information and simulation results for retrofit kits considering interactive effects between energy conservation and energy efficiency measures covering building envelope, ventilation, heating and DHW systems.

The research leading to these results has received funding from the European Regional Development Fund (EFRE-FESR/20142020) under the project KlimaKit CUP number B56J16001740001.

\section{References}

1. M. Lovati, J. Adami, D. Moser, "Open source tool for a better design of BIPV+battery system: an applied example." 2018.

2. M. Lovati, R. Albatici, L. Maturi, D. Moser, "Effect of module orientation and batteries on performance of building integrated photovoltaic system." 2017.

3. Klein, S.A. et al, 2010, TRNSYS 17: A Transient System Simulation Program, Solar Energy Laboratory, University of Wisconsin, Madison, USA, http://sel.me.wisc.edu/trnsys

4. Meteonorm by Meteotest https://meteonorm.com/en/

5. Widén, J. and E. Wäckelgård, A high-resolution stochastic model of domestic activity patterns and electricity demand. Applied Energy, 2010. 87: p. 1880-1892

6. Ashrae handbook of fundamentals 2009. Table 4 . pag. 9-6

7. G. Ward, "RADIANCE reference manual." 1996. 